\title{
The Determinants of Trade Credit Demand: An Empirical Study from Cameroonian Firms
}

\author{
Omenguele René Guy ${ }^{1} \&$ Math Mazra ${ }^{2}$ \\ ${ }^{1}$ Faculty of Economics and Management, Dschang University, Dschang, Cameroon \\ ${ }^{2}$ Faculty of Economics and Management, Ngaoundere University, Ngaoundere, Cameroon \\ Correspondence: Omenguélé René Guy, Faculty of Economics and Management, Dschang University, P.O. Box \\ 110, Dschang, Cameroon. E-mail: omenguelereneguy@yahoo.fr
}

Received: July 2, 2012 Accepted: August 13, $2012 \quad$ Published: September 1, 2012

doi:10.5539/ijbm.v7n17p43 URL: http://dx.doi.org/10.5539/ijbm.v7n17p43

\begin{abstract}
Research on trade credit has been growing in recent years, contributing to our understanding of the phenomenon. However, the main problem is probably the impact of the contingent nature of the payment practices used by companies. The purpose of this paper is to address the determinants of trade credit in the Cameroonian context. Based on a sample of 65 Cameroonian companies observed in 2006, the econometric investigations highlight a genuine financial intermediation business close to productive activity. We used a general model incorporating both financial variables, transactional and sociocultural in order to estimate the joint effect of all explanatory variables on the trade credit which is a kind of investment in business relationship. Logistic regression results confirmed the positive and significant correlation between rationing and trade credit. There is also apparent influence of contingency factors on sociocultural commercial time through social capital and ethnicity of trade and investment partners. Moreover the manager share of capital positively influences the duration of the trade credit where as the financial motive is one that mostly influences to the companies' behavior.
\end{abstract}

Keywords: trade credit, payment terms, supplier credit, informational asymmetries

\section{Introduction}

Trade credit is one of the main sources of funding for worldwide companies (Petersen and Rajan, 1995; Gustafson, 2004; Van Horen, 2007). In all economies, the volume of trade credit is higher than short-term loans received from banks (Blasio, 2005) and it results from payment intervals mutually agreed by non-financial companies.

Since Meltzer (1960) research, a substantial number of studies have investigated the determinants of using trade credit. However, almost all of these studies are devoted to industrialized economies. Only a few researches have specifically been interested on developing countries' cases (McMillan and Woodruff, 1999; Fafchamps, 1997; Demirgüç-Kunt and Maksimovic, 2001; Fisman, 2001; Isaksson, 2002; Fisman and Love, 2003).

It appears that companies operating in countries having underdeveloped and/or inefficient legal and financial system depend relatively more on trade credit (Rajan and Zingales, 1995; La Porta et al., 1998; Johnson, McMillan and Woodruff, 2002; Beck, Demirgüç-Kunt and Maksimovic, 2008; Saito and Bandeira, 2010). Similarly, the contingency effects are higher in this case (Mauro, 1995; La Porta et al. 1997; Hol and Van der Wijst, 2002; Pike et al., 2005; Sivak et al., 2012). According to a survey conducted in Cameroon in 2009 by the World Bank, nearly $16 \%$ of operating capital firms is financed by trade credit against $14 \%$ by bank loans.

Despite these enlightening statistics its importance has been long recognized (Meltzer, 1960; Brechling and Lipsey, 1963), corporate debt vis-à-vis other non-financial firms' phenomenon has not been deeply and particularly analyzed in Cameroon. Our interest in addressing this phenomenon is mainly due to the importance of financial amount involved and its economic and financial impact. Similarly, with regard to Charreaux (1998) work on corporate governance, financial research in Cameroon deserves enrichment on the relations established by the company with its trading partners, which is the subject of this study. 


\section{Literature Review}

The trade credit plays an undeniable role in corporate balance sheets in all contemporary economic systems (Ziane, 2009). However, it has a special resonance in the context of a developing economy without financial market (Fisman and Love, 2003), in transition (Hammes, 2003; Delannay and Weill, 2004; Munyo, 2006) and in emerging economies (Johnson et al., 2002; Allen, Qian and Qian, 2005; Ge and Qiu, 2007; Cull, Xu and Zhu, 2009) where the banking system can not provide a significant support to companies. Assuming that trade credit is a real form of credit, why then firms choose to finance themselves from their suppliers? Why do these suppliers agree to engage themselves in credit distribution? Theories justifying the use of trade credit are based on the imperfect nature of markets, stressing the role of information asymmetries (Emery, 1984; Smith, 1987; Atanasova, 2007) and emphasizing on financial considerations and factors related to business strategies.

\subsection{Financial Incentives}

The financial motive exists only if firms can profitably combine financial intermediation in the sale of goods because of imperfections in capital markets (Diestch, 1990). These imperfections are the cause of the phenomenon of credit rationing (Stiglitz and Weiss, 1981). Through the lengthening of payment periods delay, companies with better market access to credit are able to use the borrowing capacity to act as an intermediary for those exposed to rationing (Schwartz, 1974; Emery, 1984; Crawford, 1992a; Berlin, 2003; Deloof and Van Overfelt, 2011). This intermediation carried out by the supplier is based on three advantages. The first is the acquisition of regular information, timely, rich and less costly from borrowers who are primarily clients (Lewellen, McConnell and Scott, 1980; Biais and Gollier, 1997; Jain, 2001; Frank and Maksimovic, 2005), thereby transmitting a signal to other lenders (Cook, 1999; Boissay, 2004; Alphonse, Ducret and Séverin, 2006). From this perspective, trade credit and bank credit do not appear as exclusive financing tools (Meltzer, 1960; Petersen and Rajan, 1997; Kohler, Britton and Yate, 2000; Nilsen, 2002; Bougheas, Mateut and Mizen, 2009) and complementary (Elliehaussen and Wolken, 1993; Marrota, 2001; Burkart and Ellingsen, 2004; Saito and Bandeira, 2010; Vaidya, 2011; Atanasova, 2012). The second is the increased control power due to the risk of future supplies cessation if the customer applies a risky management method (Cunat, 2007) and in case of financial disputes (Jain, 2001). Finally, in case of client failure, suppliers have an advantage in upgrading sold products (Diestch, 1998; Myers and Rajan, 1998; Wilner, 2000; Longhofer and Santos, 2003; Frank and Maksimovic, 2005).

\subsection{Non-Financial Motives}

Theories of non-financial consider that the trade credit involves simple but essential operational considerations for business functioning (Ferris, 1981; Wilson and Summers, 2002), allows price discrimination (Brennan, Maksimovic and Zechner, 1988; Petersen and Rajan, 1997), comforts product sales promotion (Nadiri, 1969; Rodriguez-Rodriguez, 2006) and is an indicator of product quality (Smith, 1987; Emery and Nayar, 1998; Pindado and Bastos, 2007). The transaction motive is surely the most obvious reason to justify a delay between the delivery cycle and payment cycle (Elliehausen and Wolken, 1993). The temporal separation of delivery cycles and settlement implies the accumulation of invoices over a period of time savings and transaction costs related to mobilization, detention and payment processing in liquid company assets (Schwartz, 1974; Ferris, 1981; Crawford, 1992b). This motive is based essentially on the cash management simplicity (Schwartz, 1974; Ferris, 1981; Long, Malitz and Ravid, 1993). Integral component of the supplier tariff policy (Schwartz, 1974), payment intervals are also a selling point to which the competition is a strategy and sales support (Hay and Louri, 1996; Summers and Wilson, 2003). They appear as an essential part of business strategies to preserve not only the level of sales but also to attract new customers (Peel, Wilson and Howorth, 2000; Paul, 2007) and thus closely analogous to advertising (Nadiri, 1969). Trade credit serves to differentiate competing offers as well as payment facilities which determine the choice of any smart consumer. Similarly, when demand is irregular, due to uncertainty or seasonal variations, the seller may temporarily relax the terms of credit standards to drive sales in periods of low demand (Emery, 1987; Lee and Stowe, 1993; Paul and Wilson, 2006). Trade credit can also be used to discriminate price (Schwartz and Whitcomb, 1979; Brennan et al., 1988; Miam and Smith, 1992; Petersen and Rajan, 1997). The underlying hypothesis assumes that the credit terms granted to customers are mainly defined according to industry standards. Extending the credit period is synonymous to reducing prices; some riskier borrowers may have a price elasticity of demand for greater undergoing bank credit rationing. Extending payment deadlines may enable the elastic segment of the market to express its demand (Brennan et al., 1988; Miam and Smith, 1992). Losses on the price are compensated by sold quantities, so that the total profits increase (Schwartz and Whitcomb, 1978). In this financial logic, the importance of the profit realized by the seller is an essential element of the price discrimination influence. By lower effective prices and providing liquidity, the use of trade credit is an active strategy to discriminate between customers (Meltzer, 1960; Hekman, 
1981). Furthermore, Smith (1987) considers that it is possible for the seller to use trade credit as a real signal in a process similar to that mentioned in financial theory by Ross (1977), Leland and Pyle (1977). Trade credit is used as a means of avoiding such information asymmetries related to default risk of the buyer. Smith's model has largely inspired other researchers (Long et al., 1993; Lee and Stowe, 1993; Deloof and Jegers, 1996; Wei and Zee, 1997; Emery and Nayar, 1998; Pike et al., 2005; Pindado and Bastos, 2007). Informational asymmetry is not about the quality of the borrower but about the quality of the product sold by the supplier. From this perspective, the credit period can give the opportunity to reduce informational asymmetries about product quality and the seller reputation, which makes trade credit a signal of product quality and seller reputation.

\section{Methodology and Model}

\subsection{Data Collection}

The data collected for this study came from responses to a questionnaire survey in 2006 and statistics indicators on tax statements at the National Institute of Statistics. The sample selection was made according to financial criteria (excluding firms in financial sector and public owned companies due to the specificities of their management) and demographic (excluding companies having apparent anomalies, like the zero or negative values of their sales ...). This double selection criterion has reduced the initial sample to 950 companies. 450 companies received the questionnaire that was sent to the leaders. After elimination of some questionnaires on criteria of completeness and consistency, the response rate considered is $15 \%$ composed of 65 companies.

\subsection{Variables in the Model}

\subsubsection{Structural Contingency Variables}

\section{The company size (PET and GDE)}

The company size is one of the most discriminating factors when it comes to financial choices of individual firms. Since the work of Meltzer (1960), the hypothesis of the existence of a relationship between firm size and duration of trade credit is commonly tested in the literature (Petersen and Rajan, 1997; Ono, 2001; Summers and Wilson, 2002; Delannay and Weil, 2004; Pike et al., 2005; Niskanen and Niskanen, 2006; Giannetti, Burkart and Ellingsen, 2008; Pindado and Bastos, 2009; Gibilaro and Mattarocci, 2010; Vaidya, 2011; Sivak et al., 2012). However, the researchers do not agree on the meaning of the relationship, because of the existence of interaction between the client and its supplier. In theory, it appears that large firms have a relatively high bargaining power which results to larger payment intervals that may be due to the importance of contracts and the confidence they inspire. At the same time, external funding sources available for the companies are more numerous as its size is larger (Chant and Walker, 1988; Petersen and Rajan, 1997; Danielson and Scott, 2004; Niskanen and Niskanen, 2006).

Numerous indicators have been used to measure the influence of the firm size factor in most of the empirical works on trade credit. For Summers and Wilson (2002), Pike and al. (2005), Garcia-Teruel and Martinez-Solano (2008), the size criterion used is the amount of turnover, while after Chant and Waker (1988), Fisman (2004), Fabbri and Klapper (2008), the firm size is measured by the number of employees. Pindado and Bastos (2009), Hyndman and Serio (2010), Atanasova (2012), Sivak et al. (2012) have also caught the number of employees, Petersen and Rajan (1997), Niskanen and Niskanen (2006), Giannetti et al. (2008), Ziane (2009), Gama and Mateus (2010), Saito and Bandeira (2010), Deloof and Van Overfelt (2011), Vaidya (2011) have used the total assets as a measure of firm size, while Ono (2001) for example has considered the amount of equity. To control the influence of firm size, we introduced into our model a variable reflecting membership in the category of small businesses (PET: less than 50 employees) or large business (GDE: 50 or more employees).

\section{The Age of the Business (AGEE)}

Theories of static equilibrium (Modigliani and Miller, 1963; Miller, 1977; Brennan and Schwartz, 1978), agency (Jensen and Meckling, 1976) and signal (Ross, 1977; Leland and Pyle, 1977) presuppose the existence of a positive relationship between the company's life and the weight of debt. Conversely, the arguments of the theory of pecking order theory reflects the fact that older firms have more internal financing sources and rely less on debt (Myers, 1984; Myers and Majluf, 1984).The firm's age is an approximation of capital information available to its borrowers, and thus, it influences resources availability through uncertainty reduction about the repayment capacity (Chant and Walker, 1988; Petersen and Rajan, 1997; Mateut and Mizen, 2003; Niskanen and Niskanen, 2006).

A relatively old business is generally considered to have good reputation and thus gains trust from borrowers and easily establishes long lasting relationships with its bank lenders. Petersen and Rajan (1994) showed that the lifetime relationship formed by firms and financial institutions is highly correlated to the availability of bank 
loans. The degree of asymmetric information is assumed to be inversely proportional to the company's age. The operational risk is modeled through the age of the firm measured by the variable AGEE from the creation date using a simple logarithmic specification [ $\operatorname{Ln}(1+$ firm age $)]$ to estimate a kind of elasticity.

\subsubsection{Sociocultural Contingency Variables}

\section{The leader ethnicity (AIP, GMA, BAM, GPA)}

The actors are essentially cultural beings, because they are defined as much by-categories structure both singular and collective, giving them a sense of their actions (Degenne and Forse, 1994). They are carriers of norms and social values on which their ways of thinking and being. It would be risky, even reckless to conduct any reflection on the management of African firms, without taking in consideration substrates that are the cultural vehicle for both individual and collective Action (Ouattara, 1995; Mutabazi, 2001; Kamdem, 2002; Diagne, 2004; Hernandez, 2007). Cameroon, with its more than 240 tribes, and which geographical, economic and cultural configurations, are said as to be Africa in miniature offers no doubt of the contingency approach. The existence of several ethnic groups may reveal the heterogeneous managerial behavior (Brasseur, 2008). Related to managerial practices, there are several ways in which ethnicity can influence the allocation of credit, either through the propensity for discrimination (Akerlof, 1985), prejudice (Yinger, 1998), difficulties of communication across cultural barriers (Cornell and Welch, 1996; Loury, 1998), statistical discrimination (Coate and Loury, 1993), the effects of network (Saloner, 1985; Montgomery, 1991). In addition, several empirical studies have considered ethnicity as a variable likely to influence corporate behavior in the matter of trade credit (Biggs et al., 1996; Fafchamps, 1996a, 1997, 2000; Biggs et al., 2002; Isaksson, 2002; Fisman and Raturi, 2004; Aaronson et al., 2004; Coleman, 2005).

According to Kamdem and Fouda (2004), ethnicity was apprehended by four dichotomous variables (AIP, GMA, BAM, GPA).

- The area under the influence of Fulani (AIP): This area includes all groups of the North, Adamawa and Far North. These groups are characterized by high degree of solidarity (Kamdem and Fouda, 2004).

- The English minority group (CMG): it should be noticed a kind of tendency to particularism and isolationism for English minority. This group includes the North West and South West.

- The Bamileke group (BAM): it is distinguished through its dynamism, entrepreneurship and business acumen. Mveng (1985) and Warnier (1993) stressed that "Solidarity merit" is a characteristic of Grass-field populations.

- The Pahouin group and others (GPA): Bassa'a and Douala's society and Pahouin group companies that are also egalitarian societies do not show strengthen links with the group. We also noted the competition spirit and the importance of equalizing mechanisms that have always characterized the two peoples.

\section{The Social Capital of the Leader}

The social capital and network theory research were related to fields such as innovation (Landry, Amara and Lamari, 2000), entrepreneurship (Larson, 1991; Batjargal, 2000; Jack, Dodd and Anderson, 2004), the performance of individuals, teams and organizations (Nelson, 1989; Ostgaard and Birley , 1994; Ndangwa, Sonna and Djeumene, 2007; Brulhart and Puaux-Claye, 2009), mobility and career progression (Baret and Soto Maciel, 2004; Benedic et al., 2009), inter-firm relations (Barnir and Smith, 2002), etc. The mobilization of the corpus of social networks can effectively respond to problems related to inter-company financing, through the cognitive form of social capital which is confidence.

Confidence between lender and borrower is the main criteria of trade credit practices. Indeed, because the use of a formal guarantee is unrealistic for most commercial transactions, trade credit is essentially allocated on the basis of trust (Fafchamps et al., 1994), therefore a selective basis. Customers, who are not qualified, shall purchase in cash (Fafchamps, 1996b, 1997). Similarly, networks of business leader and the resulting social capital play a key role in accessing to funding by the company (Okten and Osili, 2004).

According to Stone and Hughes (2002), measures of social capital are often an amalgam and disparate data with in one hand social practices (social networks), and in another perceptions (confidence). Several studies have measured social capital (Brass and Burkhardt, 1993; Burt, 1995; Seibert, Kraimer and Liden, 2001; Barnir and Smith, 2002).

In this paper, we measure the shape of cognitive social capital by "trust", which is the most often referred in the literature on social capital. To measure the level of trust, the respondent is asked to choose on a five point scale measure how each of the stakeholders (customers, suppliers, banks, microfinance institutions, professional 
organizations) by answering the question: how much do you agree with the fact that mutual trust is important for your business transactions and in the success of your business? Depending on the overall score obtained, the variable confidence (CONF) is dichotomous taking the value 0 (low confidence) for a score below the average (12) and 1 (high confidence) for a score greater than or equal to the average, with the theoretical total score ranging from 4 to 20 .

\section{Other Variables}

Other predictors of time granted by suppliers reflect factors related to transactions and financial factors. The transactional factors are approximated using:

- The company inventory amount reported to the total assets: it is an indicator of the volume purchased (STA). Companies whose stocks have higher value have a significant volume of purchases and, therefore, express a need of increasing trade finance.

- Stock rotation (ROT) in days of sales. It is first possible to consider that firms which stocks have a fast turnaround time are subject to frequent purchases and thus face greater uncertainty, requiring higher gain credit from suppliers. Conversely, stocks that flow slowly may be associated with a particularly long production cycle or, worse, be an expression of sales problems. In both cases, higher exposure to risk can justify a claim of more consistent trade payables.

- The number of suppliers (NBF) in connection with the firm reveals the temporal variability of deliveries. Thus, a high frequency of purchases from a large number of suppliers increases a priori uncertainty and hence transaction costs associated with a simultaneous payment for deliveries.

- Turnover (CAN): in relation to opportunity costs of holding liquid assets for purposes of settlement of purchases of the company, this variable is in those positively influence suppliers on time.

- Debt (END), defined as the sum of debts reported to the equity of the company, is used to measure the financial risk of firms. A high value of this ratio is associated with a high default risk and logically a probable rationing by financial institutions.

- The legal form of organization (NCE). The distinction is made between the companies for which the responsibility of the entrepreneur is, in case of bankruptcy and solidarity on the whole of its heritage from those for which the liability is limited to the contributions of the latter. This distinction indicates the level of exposure to risk of default of the company. Under either case, the variable NCE would positively or negatively be correlated with the average credit.

- The cash discount (ESC). The price of trade credit is modeled by an indicator variable for the availability of discount mechanism when settling purchases. Thus, it is assumed that the companies for which providers give a cash discount solicit least long delays providers, both because of the high financial cost associated with the waiver of the discount period.

- The short-term bank debt (DCT). The price of bank credit is approximated by the demand for bank credit to the company. This request is the amount of short-term bank debt on the company balance sheet.

- We named firms that did not obtain all the financing from operating bank by the variable (RAT). Exposure to credit rationing should priory lead to the expression of a demand for trade credit of a longer duration from the firms involved. Table 1 outlines the different variables used and defines the various conditions. 
Table 1. Variables definition and description

\begin{tabular}{|c|c|c|}
\hline Variable & Definition & Measurement \\
\hline \multicolumn{3}{|c|}{ Dependent variable } \\
\hline DCF & Duration credit provider & $=1 \mathrm{DCF} \leq 30$ days, $=0$ otherwise \\
\hline \multicolumn{3}{|c|}{ Explanatory or independent variables } \\
\hline \multicolumn{3}{|c|}{ Transactional component } \\
\hline STAT & Volume Purchasing & Stocks/ Total Assets Balance Sheet \\
\hline CAN & Turnover & Ln (Turnover) \\
\hline NBF & Number of active suppliers & $=1$ if a number of suppliers involved in the company less than $10,=0$ otherwise \\
\hline ROT & Inventory turnover & (Inventory $* 360 /$ turnover tax (days of sales) \\
\hline \multicolumn{3}{|c|}{ Financial component } \\
\hline ESC & Cash Discount & $=1$ if use of the discount in the payment of suppliers, $=0$ otherwise \\
\hline PET & Small Business & Small Business $=1,=0$ otherwise \\
\hline GDE & Large company & $\mathrm{EDG}=1$ large firm, $=0$ otherwise \\
\hline AGEE & Age & $\operatorname{Ln}(1+$ firm age $)$ \\
\hline RCE & Legal form & $=1$ if the company is one proprietorship or general partnership, $=0$ otherwise \\
\hline END & Debt & Total Liabilities (except payables and bank CT / Equity) \\
\hline DCT & Short term bank borrowings & Borrowings and bank debt to more than 1 year / Total balance sheet assets \\
\hline RAT & Rationing & $\mathrm{RAT}=1$ if the firm is rationed in operating bank loans, $=0$ otherwise \\
\hline \multicolumn{3}{|c|}{ Sociocultural characteristics } \\
\hline AIP & Septentrion & $=1$ if the head belongs to the area under the influence Fulani, $=0$ otherwise \\
\hline BAM & Bamileke & $=1$ if the head belongs to the Bamileke, $=0$ otherwise \\
\hline GPA & Group Pahouin and other & $=1$ if the head is taken and the other group Pahouin, $=0$ otherwise \\
\hline CONF & Confidence & $=1$ for a high confidence score greater than or equal to the average $(12),=0$ otherwise \\
\hline
\end{tabular}

\subsection{The Econometric Model}

We have constructed a general model incorporating both financial, transactional and sociocultural variables in order to estimate the joint effect of all explanatory variables on the dependent variable. Logistic regression used assumes that the decision to get the credit for a given period is the manifestation of an unobservable latent variable $y_{i}^{*}$ defined by the regression relationship which follows.

$$
y_{i}^{*}=\sum_{i=1}^{K} \beta_{i} x_{i}+\varepsilon=x_{i} \beta+\sigma \varepsilon_{i}
$$

Where $\beta$ is a vector of unknown parameters related to the vector of exogenous or explanatory variable $x_{i}$.

We will therefore estimate a logit function in which the dependent variable is the probability of using credit from suppliers for a given duration, represented by a binary variable, when the characteristic values are known. We observe the realization of $y_{i}$ from the following diagram:

$$
y_{i}=\left\{\begin{array}{l}
1 \text { if supplier delay }\left(y_{i}^{*}\right) \leq 30 \text { days } \\
0 \text { if supplier delay }\left(y_{i}^{*}\right)>30 \text { days }
\end{array}\right\}
$$

The decision criteria to designate the dependent variable DCF are: 


$$
D C F=\left\{\begin{array}{c}
D C F=1 \text { if } x_{i} \beta+\delta \varepsilon_{i} \leq 30 \text { days } \\
\left.D C F=0 \text { if } x_{i} \beta+\delta \varepsilon_{i}\right)>30 \text { days }
\end{array}\right\}
$$

$\mathrm{y}_{\mathrm{i}}$ is the probability that a firm gets a supplier delay exceeding 30 days, and that $\mathrm{y}_{\mathrm{i}}-1$ the company gets a period not exceeding 30 days, knowing the characteristics $x_{1 i}, \ldots, x_{k i} .$. The log-odds logistic regression model is given by:

$$
\log \frac{y_{i}}{1-y_{i}}=\log O_{i}=\alpha+\sum_{i=1}^{K} \beta_{i} x_{i}
$$

$O_{i}$ is the conditional odds of obtaining a supplier delay of less than 30 days, given the explanatory variables $\mathrm{x}_{\mathrm{i}}$.

The $\beta$ represent the log-odds variation due to a unit change in the value of the predictor $x_{i}$.

The multiplicative version of the above equation, obtained by the exponential relationship is given as follow:

$$
O_{i}=\exp (\alpha) \times \prod_{i=1}^{K} \exp \left(\sum_{i=1}^{K} \beta_{i} x_{i}\right)
$$

Where $\exp \left(\beta_{\mathrm{i}}\right)$ is the odds ratio which is the expected change on $\mathrm{O}$. In other words, $\exp \left(\beta_{\mathrm{i}}\right)$ represents the estimated change in the odds, following a unit change in the explanatory variable (the marginal effect of the predictor variation on the log of the ratio of possibilities).

The empirical model of trade credit demand studied in this paper is given by the following equation:

$$
\begin{aligned}
D C F & =\beta_{0}+\beta_{1} S T A T+\beta_{2} C A N+\beta_{3} N B F+\beta_{4} R O T+\beta_{5} E S C+\beta_{6} P E T \\
& +\beta_{7} G D E+\beta_{8} A G E E+\beta_{9} R C E+\beta_{10} E N D+\beta_{11} D C T+\beta_{12} R A T \\
& +\beta_{13} A I P+\beta_{14} B A M+\beta_{15} G P A+\beta_{16} C O N F+\varepsilon
\end{aligned}
$$

\section{Results and Discussion}

The estimation results are presented in Table 2. Compared to other companies, companies which leaders are from the Bamileke group receive longer payment interval from suppliers when purchasing (BAM). The correlation between trade credit payment interval and ethnicity can be explained at three levels: prejudice, statistical discrimination and network effects. 
Table 2. Results

Estimation of the dependent variable (DCF): Regression coefficients of the estimation model by maximum likelihood. *,** and ***, significance at $1 \%, 5 \%, 10 \%$, respectively; - 2LL : - $2 \log$ likelihood

\begin{tabular}{|c|c|c|c|c|c|}
\hline Type of variables & variables & $\beta$ & E.S & Signif. & $\operatorname{Exp}(\beta)$ \\
\hline \multirow{4}{*}{ Transactional component } & STA & $1,053^{*}$ & 0,381 & 0,006 & 2,866 \\
\hline & CAN & $0,489^{* *}$ & 0,237 & 0,039 & 1,630 \\
\hline & NBF & $0,277^{* *}$ & 0,132 & 0,036 & 1,319 \\
\hline & ROT & $0,119^{*}$ & 0,042 & 0,005 & 1,126 \\
\hline \multirow{7}{*}{ Financial component } & PET & $-0,303^{*}$ & 0,100 & 0,002 & 0,739 \\
\hline & ESC & $-1,145$ & 0,729 & 0,116 & 0,318 \\
\hline & RCE & 0,186 & 0,134 & 0,163 & 1,204 \\
\hline & AGEE & $-0,745$ & 0,596 & 0,211 & 0,475 \\
\hline & END & $0,672^{* *}$ & 0,359 & 0,061 & 1,958 \\
\hline & DCT & $0,259^{* *}$ & 0,124 & 0,036 & 1,296 \\
\hline & RAT & $0,066^{*}$ & 0,023 & 0,003 & 1,069 \\
\hline \multirow{3}{*}{ Sociocultural variables } & AIP & 0,060 & 0,041 & 0,147 & 1,062 \\
\hline & BAM & $0,809^{* *}$ & 0,410 & 0,048 & 2,246 \\
\hline & CONF & $1,369^{*}$ & 0,531 & 0,010 & 3,932 \\
\hline \multirow{5}{*}{ Goodness fit } & \multicolumn{3}{|c|}{ Number of observations } & \multicolumn{2}{|c|}{65} \\
\hline & \multicolumn{3}{|c|}{ - 2LL: - 2LOG likelihood } & \multicolumn{2}{|c|}{50,945} \\
\hline & \multicolumn{3}{|c|}{ R2 of Cox \& Snell } & \multicolumn{2}{|c|}{0,495} \\
\hline & \multicolumn{3}{|c|}{ R2 of Nagelkerke } & \multicolumn{2}{|c|}{0,662} \\
\hline & Test of Hos1 & Lemeshow & & \multicolumn{2}{|c|}{2,18} \\
\hline
\end{tabular}

Prejudice means that the leaders from certain ethnic groups are marked with the seal of "deadbeat" or "dubious reputation managers". Therefore, members of the business dominant ethnic group choose not to grant extra time of large payments to members of other ethnic communities, considering that they are either "inexperienced" or not having good press. This rejection behavior of the others, as mentioned by Fafchamps (1996a), may be due to the fact that the dominant ethnic community wishes to continue in this leadership position indefinitely, which is somehow seems irrational.

Another explanation would result from statistical discrimination. It assumes that some leaders are more competent and less financially risky than others. Therefore, if the Bamileke group is characterized by solidarity in merit (Mveng, 1985), we can consider that Bamileke leaders represent less risk and therefore can obtain high payment interval. The disadvantage would be penalizing some credible leaders of other ethnic groups. Therefore, statistical discrimination is economically inefficient.

Another explanation is the network effects. In a particular network, there is a flow of information Greif (1993, 1994). In this regard, we can assume that the flow of information between interconnected customers and suppliers can help members of the ethnic community to identify the trusted business partners. As a result, these leaders would be reluctant to have business transactions and to grant preferential payment terms to the so called "foreigners" that they cannot easily control as their community members. This network effect plays a key role in the selection of stakeholders in the credit markets (Montgomery, 1991; Cornell and Welch, 1996). Therefore it appears some interaction between trust, trade, and ethnicity as recognized Macharia (1988) and Himbara (1994).

Moreover, confidence (CONF) is positively correlated to the dependent variable at a significance level of $1 \%$.The advantage of integrating the social capital in the context of stakeholder theory can be seen through loyalty, trust and reputation (Ballet, 2005). If the company happens to weave a set of relationships with its stakeholders, cooperation and cohesion will certainly induce gains on both sides. These reports may thus facilitate access to finance between companies when based on mutual trust.The positive impact of confidence (CONF) means that, the more the mutual trust between the company and its suppliers, the higher the company is 
likely to receive long payment interval from suppliers, enabling it to meet some immediate financing needs.

Personal relationships play a variety of valuable functions. Fafchamps and Minten (1999) reported that the Malagasy agricultural traders perceive the relationship as the most important factor for the success of their business through obtaining settlement delays and risk reduction. The positive impact and significance of the variable CONF could result from the strength of ties (Granovetter, 1973) or the degree of the social networks openness (Burt, 2005), size and prestige of the leader's social network.

Indeed, the strong bonds of ego network are characterized by the existence of frequent and regular interactions, developing close personal relationships and the emergence of a high degree of trust between actors (Nahapiet and Goshal, 1998). Also, the strong links are related to the ability to infer trust (Ingram and Roberts, 2000, Levin and Cross, 2004). They are therefore more likely to lead to resources exchange, and obtaining favorable payment terms. Barr (1998) shows that small firms in Ghana rely on their network to avoid liquidity crises.

Leaders having an extensive network of contacts are highly sought as potential partners, because cooperation with them will facilitate access to their resources (Barnir and Smith, 2002). Thus giving extensions to such enterprise means to keep them in its portfolio and access to certain resources. Granovetter (1982) mentioned that the network size is a flow channel of information.

Finally, the network members' prestige is an important resource since giving it a good reputation (Lin, 1982). In this respect, leaders with prestigious personal contacts are also seen as credible partners because prestige can send positive signals to the stakeholders (customers, suppliers, bankers) that the leader (and business) is a valuable resource (D'Aveni, 1990, D'Aveni and Kesner, 1993). In this perspective, high payment intervals from suppliers can be used strategically to retain business partners and to obtain valuable resources needed by their business at some point.

Related to financial variables, the significant and negative coefficient for the variable PET shows that the firm size appears to be an important determinant of the payment interval for a company. Large companies benefit of longer time than smaller firms from the supplier.The negative and significant relationship between the variable PET and the variable DCF highlights the relevance of the market power. Indeed, the importance of payment periods in commercial negotiation is related to the economic power of companies and therefore largely to their size. Small businesses are charged a shorter payment terms from their suppliers due to low market power. The negative correlation is also an explanation in the cost of debt and the risk of failure which can lead to loans non-repayment. Small businesses are greater risk than large businesses (Bardos, 1990).

Further the companies' age is negatively and not significantly correlated to trade credit, indicating that older firms are less indebted in duration from their trading. We can therefore believe that youngest firms, for which the level of information is considered lower due to the lack of experience and reputation, express credit need for greater financial motives, through payment interval consistence from suppliers. This result, contrary to the findings of Elliehausen and Wolken (1993), Singleton, Summers and Wilson (1999), is part of financial autonomy and independence logic vis-à-vis customers (Jain, 2001). Thus, older firms with financial strength have a lower credit risk and therefore have more access to cheaper financing alternative.

The variable debt (END) points out that the riskiest firms are those totalizing significantly higher payables than others. Given the problems of moral hazard and adverse selection that companies such as banks should consider as donors, a high volatility of profits (used as a measure of risk) can lead to an increased probability of failure, suggesting a negative relationship between credit availability and risk.

In contrast to this traditional approach, there are arguments demonstrating a positive impact of risk on the trade payables duration. In fact, when a company sees its financial condition deteriorated, it faces a higher cost of bank credit as the company is perceived as more risky. The companies are then tended to substitute trade credit to bank credit which appears to be less expensive or easier to mobilize. Creditors may be willing or required to continue to finance these firms in order to avoid bankruptcy, especially in the case of large companies with the hope of maintaining the business relationship.

Therefore, the trade credit is a kind of investment in business relationship. This result, which is further confirmed by the positive and significant correlation between the variable rationing (RAT), justifies the use of payment interval as a possibility of limiting adverse effects associated to information asymmetric on the credit market. These evidences confirm theories on informational advantage of financial intermediaries, business partners in funds provided to riskier customers (Petersen and Rajan, 1997; Menichini and Fabbri, 2010).

Moreover our results suggest that the company's legal form (RCE) and even the cost of trade credit (ESC) are not significantly explaining the demand of credit for financial reasons. Suppliers, unlike traditional financial 
intermediaries, appear to exhibit low sensitivity to certain guarantees from the client.

Conversely, the price of bank credit, quantified by the amount of short-term bank debt (DCT), significantly influences the demand of trade credit. The positive and significant impact of DCT implies that when the flow of information between companies and banks is asymmetric, the agency costs can be reduced if the company passes the necessary signals. Guarantees may be such a signal, which reduces the risk of moral hazard. The bank gets information about the company and required guaranties will reduce the amount of expected losses in case of insolvency. In this sense, companies do not replace bank financing by commercial financing, but cumulate them. This result is consistent with the theory of compromise financing (Myers, 1984) and contrary to those of the pecking order theory (Myers and Majluf, 1984) or theory of pecking ordered (Hyafil, 1995).

For the transactional component, the positive and significant coefficient of the variable (STA) indicates that a high level of transactions lead to a demand for longer payment interval when applying for trade credit. Concerning the time-based variability of transactions, the positive coefficient of the variable number of active suppliers (NBF), validates the theory that the number of average active suppliers means a high level of transactions, leading to a high degree of uncertainty in distribution and product quality, and thus, demand for a longer payment interval.

The positive link between the supplier lead time (DCF) and the rate of inventory turnover (ROT) does not reveal the influence of the transaction motive. Indeed, the increased rate of inventory turnover is not followed by the decrease of payment interval reflecting any reduction of payments frequency. The positive relationship between turnover (CAN) and the payment interval (DCF) is explained by a positive leverage of sales.

\section{Conclusion}

Our results show that the financial motive is one that mostly correlates the companies'behavior. The preeminence of this result is justified by the confirmation of the hypothesis that trade credit goes more to companies enjoying better reputation from banks than to those having lower reputation. The findings lead to a less pronounced effect of the transaction pattern. The use of payment periods is influenced by the nature of exchanges including the frequency of transactions and their amount. However, these characters are partly reflected in some aspects of the operating cycle, including the length of inventory turnover. Moreover, in relation to sociological contingencies, companies which leaders are from the Bamileke group (BAM) and North Cameroon (AIP) have longer suppliers' deadlines. Similarly, the manager share of capital positively influences the duration of the trade credit.

\section{References}

Aaronson, D., Bostic, R.W., Huck, P.F., \& Townsend, P. (2004). Supplier Relationships and Small Business Use of Trade Credit. Journal of Urban Economics, 55, 46-67.

Akerlof, G.A. (1985). Discriminatory, Status-Based Wages among Tradition-Oriented, Stochastically Trading Coconut Producers. Journal of Political Economy, 93(2), 265-276.

Allen, F., Qian, J., \& Qian, M. (2005). Law, Finance and Economic Growth in China. Journal of Financial Economics, 77(1), 57-116.

Alphonse, P., Ducret, J., \& Séverin, E. (2006). When Trade Credit Facilitates Access to Bank Finance: Evidence from US Small Business Data. MFS (Istanbul) meetings Paper, $34 \mathrm{p}$.

Atanasova, C.V. (2007). Acess to Institutionnal Finance and the Use of Trade Credit. Financial Management, $36(1), 49-67$.

Atanasova, C. (2012). How Do Firms Choose Between Intermediary and Supplier Finance? Financial Management, 41(1), 207-228.

Balandier, G. (1982). Sociologie Actuelle de l'Afrique Noire ( $4^{\text {th }}$ Ed.). Paris, PUF.

Ballet, J. (2005). Stakeholders et capital social. Revue Française de Gestion, 156, 77-91. Retrieved from http://www.cairn.info/article.php?ID_REVUE=RFG\&ID_NUMPUBLIE=RFG_156\&ID_ARTICLE=RFG_ 156_0077

Bardos, M. (1990). Le crédit plus cher pour les petites entreprises. Economie et Statistique, 236, 51-64.

Baret, C., \& Maciel Soto, A. (2004). Apports et limites de la mesure du capital social en recherche en gestion des ressources humaines. Communication au XVème Congrès AGRH, Montréal $1^{\mathrm{er}}$ au 4 septembre, $23 \mathrm{p}$.

Barnir, A., \& Smith, K. A. (2002). Interfirm Alliances in Small Business: The Role of Social Networks. Journal of Small Business Management, 40(3), 219-232. 
Barr, A.M. (1998). Social Capital and Technical Information Flows in the Ghanaian Manufacturing Sector. Center for the Study of African Economies, Oxford University, Oxford, mimeograph, 25p.

Bastos, R., \& Pindado, J. (2007). An agency model to explain trade credit policy and empirical evidence. Applied Economics, 39, 2631-2642.

Bastos, R., \& Pindado, J. (2009). Trade Credit, Creditor Protection and Accounting Standards: Evidence from an International. Revista de Economia Financiera, 17, 10-33.

Batjargal, B. (2000). Social Capital and Entrepreneurial Performance in Russia: A Panel Study. Working Paper n 352,43 p.

Beck, T., Demirgüç-Kunt, A., \& Maksimovic, V. (2008). Financing Patterns around the World: Are Small Firms Different?. Journal of Financial Economics, 89(3), 467-487.

Benedic, M., Valoggia, P., Rousseau, A., \& Schmitt, C. (2009). Gestion des connaissances et capital social : quelles interrelations?. Revue Management et Avenir, 27, 152-170.

Berlin, M. (2003). Why do Production Firms Act as Financial Intermediaries?. Business Review, 3, 21-28.

Biais, B., \& Gollier, C. (1997). Trade Credit and Credit Rationing. Review of Financial Studies, 10(4), 903-937.

Biggs, T., Raturi, M., \& Srivastava, P. (1996). Enforcement of Contracts in an African Credit Market: Working Capital Financing in Kenyan Manufacturing. RPED Discussion papers, World Bank, Washington DC, 35 p.

Biggs, T., Raturi, M., \& Srivastava, P. (2002). Ethnic Networks and Access to Credit: Evidence from the Manufacturing Sector in Kenyan. Journal of Economic Behavior \& organisation, 49(4), 473-486.

Boissay, F. (2004). Crédits interentreprises et délais de paiement : une théorie financière. Annales d'Economie et de Statistique, 73, 101-118.

Bougheas, S., Mateut, S., \& Mizen, P. (2009). Corporate Trade Credit and Inventories: New Evidence of a Trade-Off from Accounts Payable and Receivable. Journal of Banking \& Finance, 33(2), 300-307.

Brass, D., \& Burkhardt, M. (1993). Potential Power and Power Use: An Investigation of Structure and Behavior. Academy of Management Journal, 36(3), 441-472.

Brasseur, M. (2008). Le rôle des stéréotypes dans le management de la diversité culturelle: cas de l'Afrique. Revue des Sciences de Gestion, 230, 61-67.

Brechling, F., \& Lipsey, R. (1963). Trade Credit and Monetary Policy. The Economic Journal, 73(292), 618-641.

Brennan, M.J., Maksimovic, V., \& Zechner, J. (1988). Vendor Financing. Journal of Finance, 43(5), 1127-1141.

Brennan, M., \& Schwartz, E. (1978). Corporate Income Taxes, Valuation and the Problem of Optimal Capital Structure. Journal of Business, 51(1), 103-114.

Brulhart, F., \& Claye-Puaux, S. (2009). Réseau, capital social et performance pour l'organisation: le cas des responsables de sites de prestation logistique. Revue management \& avenir, 24, 65-82.

Burkart, M., \& Ellingsen, T. (2004). In Kind Finance: A Theory of Trade Credit. American Economic Review, 94(3), 569-590.

Burt, R.S. (1995). Le capital social, les trous structuraux et l'entrepreneur. Revue Française de Sociologie, 36(4), 599-628.

Burt, R.S. (2005). Brokerage and Closure: An Introduction to Social Capital. New York: Oxford University Press.

Chant, E.M., \& Walker, D.A. (1988). Small Business Demand for Trade Credit. Applied Economics, 20, 861-876.

Charreaux, G. (1998). Le rôle de la confiance dans le système de gouvernance des entreprises. Economie et sociétés-Sciences de Gestion, 8/9, 47-65.

Coate, S., \& Loury, G.C. (1993). Will Affirmative Action Policies Eliminate Negative Stereotypes ?. American Economic Review, 83(5), 1220-1240.

Coleman, S. (2005). Is there a Liquidity Crisis for Small, Black-Owned Firms?. Journal of Developmental Entrepreneurship, 10(1), 29-47. 
Conso, P. (1979). Le crédit interentreprises: un phénomène inévitable ?. Analyse Financière, $36\left(1^{\mathrm{er}}\right.$ trimestre), 24-25.

Cook, L. D. (1999). Trade Credit and Bank Finance: Financing Small Firms in Russia. Journal of Business Venturing, 14, 493-518.

Cornell, B., \& Welch, I. (1996). Culture, information and screening discrimination. Journal of Political Economy, 104(3), 542-571.

Crawford, P. (1992a). Trade Credit and Credit Rationing. Working paper $n^{\circ}$ 92/323, Department of Economics, University of Bristol, $20 \mathrm{p}$.

Crawford, P. (1992b). A Survey of the Trade Credit Literature. Working paper $n^{\circ}$ 92/324, Department of Economics, University of Bristol, $25 \mathrm{p}$.

Cull, R., Xu, L. C., \& Zhu, T. (2009). Formal Finance and Trade Credit during China's Transition. Journal of Financial Intermediation, 18(2), 173-192.

Cunat, V. (2007). Trade Credit: Supplier Debt Collectors and Insurance Providers. Review of Financial Studies, 20(2), 491-527.

D’Aveni, R.A. (1990). Top Managerial Prestige and Organizational Bankruptcy. Organization Science, 1(2), 121-142.

D'Aveni, R.A., \& Kesner, I.F. (1993). Top managerial prestige, power, and the tender offer response: a study of elite social networks and target firm cooperation during takeovers. Organization Science, 4(2), 123-151.

Danielson, M.G., \& Scott, J.A. (2004). Bank Loan Availability and Trade Credit Demand. The Financial Review, $39,579-600$.

Degenne, A., \& Forse, M. (1994). Les réseaux sociaux. Une analyse structurale en sociologie. Paris, Armand Colin, Coll. «U Sociologie », 288 p.

Delannay, A.-F., \& Weill, L. (2004). The Determinants of Trade Credit in Transition Countries. Economic Change and Restructuring, 37(3/4), 173-193.

Deloof, M., \& Jegers, M. (1996). Trade Credit, Product Quality, and Intragroup Trade: Some European Evidence. Financial Management, 25(3), 33-43.

Deloof, M., \& Jegers, M. (1999). Trade Credit, Corporate Groups and the Financing of Belgians Firms. Journal of Business, Finance and Accounting, 26(7-8), 945-966.

Deloof, M., \& Van Overfelt, W. (2011). Trade credit and bank relationships: evidence from pre-World War I Belgium. Applied Economics, 43(13), 1647-1655.

Demirguc-Kunt, A., \& Maksimovic, V. (2001). Firms as Financial Intermediaries: Evidence from Trade Credit Data, Policy. Research Working Paper n²696, The World Bank, Washington DC 50 p.

Diagne, B.I. (2004). L'ajustement culturel des entreprises africaines. Retrieved from http://fr.allafrica.com/stories/200401290619.html.

Diamond, D.W. (1991). Monitoring and Reputation: The Choice between Bank Loans and Directly Placed Debt. Journal of Political Economy, 38, 211-232.

Diestch, M. (1990). Le crédit interentreprises : coûts et avantages. Economie et Statistique, 236(1), 65-79.

Diestch, M. (1998). Atouts et handicaps du crédit client face au crédit bancaire. Revue d'Economie Financière, 46, 175-193.

Elliehausen, G.E., \& Wolken, J.D. (1993). The Demand for Trade Credit: an Investigation of Motives for Trade Credit Use by Small Firms. Staff Study Board of Governors of Federal Reserve System, n 165, 18 p.

Emery, G.W. (1984). A Pure Financial Explanation for Trade Credit. Journal of Financial and Quantitative Analysis, 19(3), 271-285.

Emery, G.W. (1987). An Optimal Financial Response to Variable Demand. Journal of Financial and Quantitative Analysis, 22(2), 209-225.

Emery, G.W., \& Nayar N. (1998). Product Quality and Payment Policy. Review of Quantitative Finance and accounting, 10, 269-284.

Fabbri, D., \& Klapper, L.F. (2008). Market Power and the Matching of Trade Credit Terms, World Bank Policy 
$\begin{array}{llllll}\text { Research } & \text { Working } & \text { Paper } & \mathrm{n} & 4754 . & \text { Retrieved }\end{array}$ http://siteresources.worldbank.org/INTFR/Resources/FabbriKlapper0408.pdf

Fabbri, D., \& Menichini, A.M.C. (2010). Trade Credit, Collateral Liquidation, and Borrowing Constraints. Journal of Financial Economics, 96(3), 413-432.

Fafchamps, M. (1996a). Ethnicity and Markets: Supplier Credit in African Manufacturing. RPED paper n 74, 41 p.

Fafchamps, M. (1996b). The Enforcement of Commercial Contracts in Ghana. World Development, 24(3), 427-448.

Fafchamps, M. (1997). Trade Credit in Zimbabwean Manufacturing. World Development, 25(5), 795-815.

Fafchamps, M. (2000). Ethnicity and Credit in African Manufacturing. Journal of Development Economics, 61(1), 205-235.

Fafchamps, M., Biggs, T., Conning, J., \& Srivastava, P. (1994). Enterprise Finance in Kenya. RPED Paper n57, Africa Region, The World Bank, Washington DC, $179 \mathrm{p}$.

Fafchamps, M., \& Minten, B. (1999). Relationship and Traders in Madagascar. Journal of Development Studies, $35(6), 1-35$.

Ferris, J.S. (1981). A Transactions Theory of Trade Credit Use. Quarterly Journal of Economics, 96(2), 243-270.

Fisman, R.J. (2001). Trade Credit and Productive Efficiency in Developing Countries. World Development, 29(2), 311-321.

Fisman, R.J. (2003). Ethnic Ties and the Provision of Credit : Relationship Level Evidence from African Firms. Advances in Economics Analysis \& Policy, 3(1). Retrieved from http://www.Bepress.com/bejeap/advances/vol3/iss1/art4

Fisman, R.J., \& Love, I. (2003). Trade Credit, Financial Intermediary Development and Industry Growth. Journal of Finance, 58(1), 353-374.

Fisman, R.J., \& Raturi, M. (2004). Does Competition Encourage Credit Provision? Evidence from African Trade Credit Relationship. Review of Economics and Statistics, 86(1), 345-352.

Fouda Ongodo, M. (2004). Valeurs culturelles des Pahouins d'Afrique Centrale et management des organisations. Actes du Colloque international organisé par la CIDEGEF et le CEMADIMO, Beyrouth (Liban) 28-29 octobre, $21 \mathrm{p}$.

Frank, M.Z., \& Maksimovic, V. (2005). Trade Credit, Collateral, and Adverse Selection. SSRN Working Paper Series. Retrieved from http://ssrn.com/abstract $=87868$

Gama, A.P.M., \& Mateus, C. (2010). Does Trade Credit Facilitate Access to Bank Finance? An Empirical Evidence from Portuguese and Spanish Small and Medium Size Enterprises. International Research Journal of Finance and Economics, 45, 26-45.

García-Teruel, P.J., \& Martínez-Solano, P. (2010). A Dynamic Approach to Accounts Receivable: A Study of Spanish SMEs. European Financial Management, 16(3), 400-421.

Ge, Y., \& Qiu, J. (2007). Financial Development, Bank Discrimination and Trade Credit. Journal of Banking \& Finance, 31(2), 513-530.

Giannetti, M., Burkart M., \& Ellingsen T. (2011). What You Sell Is What You Lend? Explaining Trade Credit Contracts. Review of Financial Studies, 24(4), 1261-1298.

Gibilaro, L., \& Mattarocci G. (2010). Predictors of Net Trade Credit Exposure: Evidence from the Italian Market. International Journal of Business and Finance Research, 4(4), 103-119.

Granovetter, M. (1973). The Strength of Weak Ties. American Journal of Sociology, 78(6), 1360-1380. Retrieved from http://www.jstor.org/stable/2776392

Granovetter, M. (1983). The Strength of Weak Ties: A Network Theory Revisited. In Sociological Theory Randal C (Ed.), San Francisco, pp. 201-233.

Granovetter, M. (1985). Economic Action and Social Structure: The Problem of Embeddedness. American Journal of Sociology, 91(3), 481-510. Retrieved from http://www.jstor.org/stable/2780199

Greif, A. (1993). Contract Enforceability and Economic Institutions in Early Trade: the Maghribi Traders'coalition. American Economic Review, 83(3), 525-548. 
Greif, A. (1994). Cultural Beliefs and the Organization of Society: A Historical and Theoretical Reflection on Collectivist and Individualist Societies. Journal of Political Economy, 102(5), 912-950.

Guido De Blasio (2005). Does Trade Credit Substitute for Bank Credit? Evidence from Firm-Level Data. Economic Notes by Banca Monte dei Paschi di Siena SpA, 34(1), 85-112.

Gustafson, C.R. (2004). Agribusiness Trade Credit - A Paradox. Agribusiness and Applied Economics Report No. $534,16 \mathrm{p}$.

Hammes, K. (2003). Trade Credits in Transition Economies. Working paper, Department of Economics, School of Economics and Commercial Law, Göteborgs Universitet, 31 p.

Hay, D., \& Louri, H. (1996). Demands for Short-Term Assets and Liabilities by UK Quoted Companies. Applied Financial Economics, 6, 413-420.

Hekman, C.R. (1981). The Effect of Trade Credit on Price and Price Level Comparisons. Review of Economics and Statistics, 526-532.

Hernandez, E.-M. (2007). Entre tradition et modernité, proposition d'un modèle de management africain. Gestion 2000, 24(1).

Himbara, D. (1994). The Failed Africanisation of Commerce and Industry in Kenya. World Development, 22(3), 469-482.

Hol, S., \& Wijst Van, D.N. (2002). Trade Credit in Europe. $31^{\text {st }}$ Meeting of the European Working Group on Financial Modeling (EWGFM), November 7-9, Agia Napa, CYPRUS, 16 p.

Huault, I. (2004). Une analyse des réseaux sociaux est-elle utile pour le management ?. In Huault I. (coord.), Institutions et gestion (pp. 30-49), Vuibert, FNEGE, Paris.

Hyafil, A. (1995). Structures financières : des théories distinctes, des choix qui convergent. Revue Française de Gestion, 106, 55-64.

Hyndman, K., \& Serio, G. (2010). Competition and Inter-Firm Credit: Theory and Evidence from Firm-Level Data in Indonesia. Journal of Development Economics, 93(1), 88-108.

Ingram, P., \& Roberts, P.W. (2000). Friendships among Competitors in the Sydney Hotel Industry. American Journal of Sociology, 106(2), 387-424.

Isaksson, A. (2002). Trade Credit in Kenyan Manufacturing. Working paper n 4, Statistics and Information Networks Branch of UNIDO, $28 \mathrm{p}$.

Jack, S.L., Dodd, S.D., \& Anderson, A.R. (2004). Social Structures and Entrepreneurial Networks: The Strength of Strong Ties. International Journal of Entrepreneurship and Innovation, 5(2), 107-128.

Jensen, M., \& Meckling, W. (1976). Theory of the firm: Managerial behavior, agency costs and capital structure. Journal of Financial Economics, 3(4), 305-360. Retrieved from www.sfu.ca/ wainwrig/Econ400/jensen-meckling.pdf

Jain, N. (2001). Monitoring Costs and Trade Credit. Quarterly Review of Economics and Finance, 41(1), 89-110.

Johnson, S., McMillan, J., \& Woodruff, C (2002). Courts and Relational Contracts. Journal of Law, Economics and Organization, 18, 221-277.

Kamdem, E. (2002). Management et interculturalité en Afrique: Expérience camerounaise. Les Presses Universitaires de Laval / Les éditions de l'IQRC, en coédition avec L'Harmattan, Québec, 433 p.

Kamdem, E., \& Fouda Ongodo, M. (2004). Faits et méfaits de l'ethnicité dans les pratiques managériales au Cameroun. Actes du Colloque international organisé par la CIDEGEF et le CEMADIMO, Beyrouth (Liban) 28-29 octobre, $24 \mathrm{p}$.

Kohler, M., Britton, E., \& Yates, T. (2000). Trade Credit and Monetary Transmission Mechanism. Discussion paper, Bank of England, 22 p.

La Porta, R., Lopez-De-Silanes, F., Shleifer, A., \& Vishny, R.W. (1997). Legal Determinants of External Finance. Journal of Finance, 52(3), 1131-1150.

La Porta, R., Lopez-De-Silanes, F., Shleifer, A., \& Vishny, R.W. (1998). Law and Finance. Journal of Political Economy, 106, 1113-1155.

Lallement, M. (2006). Capital social et théories sociologiques. In Bevort A. et Lallement M. (dirs), Le capital social-Performance, équité et réciprocité (pp. 71-88). La Découverte, Bibliothèque du MAUSS. 
Landry, R., Amara, N., \& Lamari, M. (2000). L'influence du capital social sur les décisions d'innovation des entreprises manufacturières. Département de science politique, Université Laval, Québec, 27 p.

Larson, A. (1991). Partner Networks: Leveraging External Ties to Improve Entrepreneurial Performance. Journal of Business Venturing, 6(3), 173-188.

Lee, Y.W., \& Stowe, J.D. (1993). Product Risk, Asymmetric Information, and Trade Credit. Journal of Financial and Quantitative Analysis, 28(2), 285-300.

Leland, H., \& Pyle, D. (1977). Informational Asymmetries, Financial Structure and Financial Intermediation. Journal of Finance, 32(2), 371-387.

Levin, D.Z., \& Cross, R. (2004). The Strength of Weak Ties You Can Trust: The Mediating Role of Trust in Effective Knowledge Transfer. Management Science, 50(11), 1477-1490.

Lewellen, W., McConnell, J., \& Scott, J. (1980). Capital Market Influences on Trade Credit Policies. Journal of Financial Research, 9, 105-113.

Lin, N. (1982). Social Resources and Instrumental Action. In Social Structure and Network Analysis. Ed, PV Marsden and N, Lin, Beverly Hills, Calif: Sage, pp. 131-146.

Long, M.S., Malitz, I.B., \& Ravid, S.A. (1993). Trade Credit, Quality Guarantees, and Product Marketability. Financial Management, 22(4), 117-127.

Longhofer, S.D., \& Santos, J.A.C. (2003). The paradox of priority. Financial Management, 32(1), 69-81.

Loury, G.C. (1998). Discrimination in The Post-Civil Rights Era: Beyond Market Interactions. Journal of Economic Perspectives, 12(2), 117-126.

Macharia, K. (1988). Social Networks: Ethnicity and The Informal Sector in Nairobi. WP n463, Institute for Development Studies, University of Nairobi, 25 p.

Marrota, G. (2001). Is Trade Credit More Expensive than Banks Loans? Evidence from Italian Firm-Level Data. Working paper, Mimeo, Dipartimento di Economia Politica, Università di Modena e Reggio Emilia, 35 p.

Mauro, P. (1995). Corruption and Growth. Quarterly Journal of Economics, 110(3), 681-712.

Mateut, S., \& Mizen, P. (2002). Trade Credit and Bank Lending : An Investigation into the Determinants of UK Manufacturing Access to Trade Credit. Experian Centre for Economic Modelling (ExCEM), University of Nottingham, $25 \mathrm{p}$.

McMillan, J., \& Woodruff, C. (1999). Interfirm Relationships and Informal Credit in Vietnam. Quarterly Journal of Economics, 114(4), 1285-1320.

Meltzer, A.H. (1960). Mercantile Credit Monetary Policy, and Size of Firms. The Review of Economics and Statistics, 42(4), 429.

Mian, S.L., \& Smith, C.W. (1992). Accounts Receivable Management Policy: Theory and Evidence. Journal of Finance, 47(1), 169-200.

Miller, M. H. (1977). Debt and Taxes. Journal of Finance, 32(2), 261-275.

Modigliani, F., \& Miller, M. H. (1963). Corporate Income Taxes and the Cost of Capital: A Correction. American Economic Review, 53(3), 433-443.

Montgomery, J.D. (1991). Social Networks and Labor-Market Outcomes: Toward an Economic Analysis. American Economic Review, 81(5), 1408-1418.

Munyo, I. (2006). The Financial Structure of Firms in An Economy Without Capital Markets. Revista de Ciencias Empresariales y Economica, n 5, Universidad de Mondevideo, 131-149.

Mutabazi, E. (2001). Multiculturalisme et gouvernement des sociétés africaines. Sociologies Pratiques, 5, 95-118.

Mveng, E. (1985). Histoire du Cameroun. Tome 2, CEPER, Yaoundé, 316 p.

Myers, S.C. (1984). The capital structure puzzle. Journal of Finance, 39(3), pp. 575-592.

Myers, S.C., \& Majluf, N.S. (1984). Corporate financing and investment decisions when firms have information that investors do not have. Journal of Financial Economics, 13(2), pp. 187-221.

Myers, S.C., \& Rajan, R. (1998). The paradox of liquidity. Quarterly Journal of Economics, 113(3), 733-771.

Nadiri, M.I. (1969). The Determinants of Trade Credit in the U.S. Total Manufacturing Sector. Econometrica, 
$37(3), 408-423$.

Nahapiet, J., \& Ghoshal, S. (1998). Social Capital, Intellectual Capital in the Organizational. Academy of Management Review, 23(2), 242-266.

Ndangwa, L., Sonna, F.D., \& Djeumene, P. (2007). Réseau social du dirigeant et performance de la TPE. Revue des Sciences de Gestion, 223, 75-85.

Nelson, R.E. (1989). The Strength of Strong Ties: Social Networks and Intergroup Conflict in Organization. Academy of Management Journal, 32(2), 377-401.

Nelson, R.R., \& Winter, S.J. (1982). An Evolutionary Theory of Economic Change. Cambridge Mass Boston, Harvard University Press, $437 \mathrm{p}$.

Nilsen, J.H. (2002). Trade Credit and the Bank Lending Channel. Journal of Money, Credit, and Banking, 34(1), 226-253.

Niskanen, J., \& Niskanen, M. (2006). The Determinants of Corporate Trade Credit Policies in Bank-Dominated Financial Environment: The Case of Finish Small Firms. European Financial Management, 12(1), 81-112.

Okten, C., \& Osili, U.O. (2004). Social Networks and Credit Access in Indonesia. World Development, 32(7), $1225-1246$.

Ono, M. (2001). Determinants of Trade Credit in Japanese Manufacturing Sector. Journal of the Japanese and International Economies, 15, 160-177.

Ostgaard, T.A., \& Birley, S. (1994). Personal Networks and Firm Competitive Strategy - A Strategic or Coincidental Match?. Journal of Business Venturing, 9(4), 281-305.

Ouattara, I. (1995). Management et culture : les fondements de la nécessité d'une adaptation. Le cas de l'Afrique. Humanisme \& Entreprises, 213, 45-66.

Paul, S. (2007). Theories of Trade Credit: A Reference Article. Credit Management, April, 20-22.

Paul, S., \& Wilson, N. (2006). Trade Credit Supply: An Empirical Investigation of Companies Level Data. Journal of Accounting-Business \& Management, 13, 85-113.

Peel, M.J., Wilson, N., \& Howorth, C. (2000). Late Payment and Credit Management in The Small Firm Sector. Empirical Evidence. International Small Business Journal, 18(2), 17-37.

Petersen, M.A., \& Rajan, R.G. (1994). The Benefits of Lending Relationship: Evidence from Small Business Data. Journal of Finance, 49(1), 3-37.

Petersen, M.A., \& Rajan, R.G. (1995). The Effect of Credit Market Competition on Lending Relationship. Quarterly Journal of Economics, 110(2), 407-443.

Petersen, M.A., \& Rajan, R.G. (1997). Trade Credit: Theories and Evidence. Review of Financial Studies, 10(3), 661-691.

Pike, R., Cheng, N.S., Cravens, K., \& Lamminmaki, D. (2005). Trade Credit Terms, Asymmetric Information and Price Discrimination: Evidence from three Continents. Journal of Business Finance \& Accounting, 32(5/6), 1197-1236.

Portes, A. (1998). Social Capital: its Origins and Applications in Modern Sociology. Annual Review of Sociology, 24(1), 1-24.

Rajan, R.G., \& Zingales, L. (1995). What do we know about Capital Structure? Some Evidence from International Data. Journal of Finance, 50(5), 1421-1460.

Rodriguez-Rodriguez, O. M. (2006). Trade Credit in Small and Medium Size Firms : An Application of the System Estimation with Panel Data. Small business Economics, 27(2-3), 103-126.

Ross, S. (1977). The Determination of Financial Structure: The Incentive Signalling Approach. Bell Journal of Economics, 8(1), 23-40.

Saito, R., \& Bandeira, M.L. (2010). Empirical Evidence of Trade Credit Uses of Brazilian Publicly-Listed Companies. Brazilian Administration Review (BAR), 7(3), 242-259. Retrieved from http://www.anpad.org.br/bar

Saloner, G. (1985). Old Boy Networks as Screening Mechanisms. Journal of Labor Economics, 3(3), 255-267.

Schwartz, R.A. (1974). An Economic Model of Trade Credit. Journal of Financial and Quantitative Analysis, 9(4), 
643-657.

Schwartz, R.A., \& Whitcomb, D.K. (1978). Implicit Transfers in The Extension of Trade Credit. In Bounding E. et Wilson T.F. (dirs), Redistribution through the Financial System: The Grants Economics of Money and Credit (pp. 191-208). Praeger Special Studies, New York.

Schwartz, R.A., \& Whitcomb, D.K. (1979). The Trade Credit Decision. In BICKSLER J.L. (ed), Handbook of financial economics, (pp. 257-273). North Holland, chapter 12.

Seibert, S., Kraimer, M., \& Liden, R. (2001). A Social Capital Theory of Career Succees. Academy of Management Journal, 44(2), 219-237.

Singleton, C., Summers, B., \& Wilson, N. (1999). Small Business Demand for Trade Credit, Credit Rationing and the Late Payment of Commercial Debt: An Empirical Study. In Wright M. et Robbie K. (eds), Management Buy-Outs and Venture Capital: Into the Next Millenium, 181-201.

Sivak, R., Caplanova, A., Hudson, J., \& Hudson, C. (2012). An Analysis of Firm Credit Across the World. Global Conference on Business \& Finance Proceedings, 7(1), 24-38.

Smith, J.K. (1987). Trade Credit and Informational Asymmetry. Journal of Finance, 42(4), 863-872.

Stiglitz, J.E., \& Weiss, A. (1981). Credit Rationing in Markets with Imperfect Information. American Economic Review, 71(3), 393-410.

Stone, W., \& Hughes, J. (2002). Social Capital: Empirical Meaning and Measurement Validity. Research paper n27, Australian Institute of Family Studies, $70 \mathrm{p}$.

Summers, B., \& Wilson, N. (2002). An Empirical Investigation of Trade Credit Demand. International Journal of the Economics of Business, 9(2), 257-270.

Summers, B., \& Wilson, N. (2003). Trade Credit and Customer Relationships. Managerial and Decision Economics, 24(6/7), 439-455.

Vaidya, R.R. (2011). The Determinants of Trade Credit: Evidence from Indian Manufacturing Firms. Modern Economy, 2, 707-716.

Van Horen, N. (2007). Customer market power and the provision of trade credit: evidence from Eastern Europe and Central Asia. World Bank Policy Research Working Paper n 4284. Retrieved from http://wvy-wwdsworldbank.org/servlet/WDSContentServer/WDSP/IB/2007/07/25/000158349_2007072515 0007/Rendered/PDF/WPS4284.pdf

Warnier, J.P. (1993). L'esprit d'entreprise au Cameroun. Karthala, Paris, 307 p.

Wei, P., \& Zee, S.M.L. (1997). Trade Credit as Quality Signal: An International Comparison. Managerial Finance, 23, 63-72.

Wilner, B.S. (2000). The Exploitation of Relationships in Financial Distress: The Case of Trade Credit. Journal of Finance, 55(1).

Wilson, N., \& Summers, B. (2002). Trade Credit Terms Offered by Small Firms: Survey Evidence and Empirical Analysis. Journal of Business Finance \& Accounting, $29(3$ \& 4), 317-351.

Yinger, J. (1998). Evidence on Discrimination in Consumer Markets. Journal of Economic Perspectives, 12(2), $23-40$.

Ziane, Y. (2009). Tests des motifs transactionnels et financiers du crédit commercial. Finance Contrôle Stratégie, 12(1), 67-92. 